\title{
Residents' Perceptions toward Coastal and Dune Management: An Evaluation of the Hightown Dune Restoration Project (HDRP), UK
}

\author{
Md Ataur Rahman Khan ${ }^{1,2}$ \\ ${ }^{1}$ Department of Geography \& Environmental Science, Liverpool Hope University, Hope Park, Liverpool, UK \\ ${ }^{2}$ Development Planning Branch, Ministry of Railways, Government of the People's Republic of Bangladesh, \\ Dhaka, Bangladesh \\ Correspondence: Md Ataur Rahman Khan, Development Planning Branch, Ministry of Railways, Government of \\ the People's Republic of Bangladesh, 16 Abdul Ghani Road, Dhaka 1000, Bangladesh. Tel: 88-02-958-9006; \\ 88-017-1399-2292. E-mail: khanataur71@yahoo.com
}

Received: June 27, 2015 Accepted: July 23, 2015 Online Published: September 27, 2015

doi:10.5539/jsd.v8n8p121 URL: http://dx.doi.org/10.5539/jsd.v8n8p121

\begin{abstract}
Residents' perceptions are intangible ideas that may impact tangibly on coastal and dune management strategy and contribute truly for the sustainability of coast and dune restoration project. This study utilizes a qualitative approach to investigate residents' perceptions of the effectiveness of the measures implemented by Sefton Council to protect the Hightown dunes and coast from the risks of coastal erosion and flooding, and preserve local biodiversity. Findings revealed that residents regarded the measures as ineffective and considered the area safe so long as climatic conditions remained consistent. The study highlights the necessity of local community involvement in comprehensive coast and dune management plans to ensure project sustainability.
\end{abstract}

Keywords: coast and dune management, community involvement, residents' perception, UK

\section{Introduction}

The study of human perceptions of the environment was developed by anthropologists and provided an important framework for environmental protection and resource management practices (Campos et al., 2012). Local people possess a diverse range of indigenous ecological and environmental knowledge developed through prolonged relations with and through the use of resources in a place of a particular cultural and environmental context (Roth, 2004; Warren et al., 1995). Such knowledge shapes their perceptions and attitudes (Alkan et al., 2009; Campos et al., 2012; Jim and $\mathrm{Xu}, 2002$ ). Perception refers to the beliefs people develop through their experiences and interaction with a particular program or activity (Htun et al., 2012) and is manipulated by cultural, contextual, experiential and individual factors that bring about interpretation (Bell, 2001).

Local people's perceptions are associated with the costs and benefits, their knowledge and dependence on the resources of a designated area (Xu et al., 2006). Local residents are the immediate beneficiaries of a neighboring coast and simultaneously they are the direct victims of any coastal risks or calamities. Therefore, their perceptions, observations and experiences of coastal and dune management, and their concerns about safety, satisfaction and sustainability are vital for the evaluation and improvement of local coastal defense projects. Community involvement and participation therefore, should be a fundamental requirement.

Community involvement in coastal and dune management projects opens up opportunities for collaboration that lead to well-organized policy, increased government responsibility, enhanced sustainability of the initiatives, lower community tensions, and reduce conflicts arising from competing agendas, socio-cultural differences and economical concerns (Ernoul, 2010; French, 2004). The philosophy of public participation is now so deeply entrenched that obtaining EU funding is practically impossible for environmental management proposals that exclude a strongly developed public participation component (McKenna and Cooper, 2006). Stakeholder participation is now an imperative to the extent that coastal management literature no longer stresses if, but rather how this should be realized (King, 2003).

In the following sections I first provide an overview of the relevant literature on participatory approaches of coastal and dune management, as well as the current state of coastal zone management research in the UK. We then detail our research strategy and methodology, followed by a report of key findings and discussion of their 
implications. The final section concludes the paper.

\section{Participatory Approaches \& Current State of Coastal and Dune Management}

Successful coastal zone management requires participatory planning, a modern trend of public empowerment that prevents top-down, centralized prescriptive management and promotes bottom-up, decentralized participatory approaches (European Parliament and Council, 2002; McKenna and Cooper, 2006). However, given that different stakeholders each have their own vested interests as they compete and contend for resources, achieving high levels of cross-sectoral co-operation is likely to be a difficult task (European Commission, 2010).

Although research (Stojanovic and Ballinger, 2009) identifies public participation as a problem in the misinformation of coastal management and points to poor understanding of dune ecology and management in spite of high levels of awareness, the role of the general public cannot be understated. Rather, such research points to an increased need for training, leadership and enhanced communication among government authority, voluntary sector and the public. Although not necessarily scientifically trained, local residents can be well informed about the local area, and possess relevant information about the processes, nature and general behavior of coastline.

Today's coastal defense schemes are topics of increasing public inquiry because global issues such as climate change and rising sea levels form an increasing part of the general public's perception of modern life (French, 2006). Therefore, the methods and approaches of coastal defense need to be accountable to the public. With respect to dune management two main camps can be identified from the literature (French, 2004). The majority camp argues that giving or losing land to the sea should not be a choice and thus advocate the use of hard defenses such as sea walls. On the contrary, the minority camp campaigns for the long term benefit of soft techniques (Nordstrom, 2008). Whatever strategy is eventually adopted should be in consideration of issues such as public acceptability, cost and sensitivity (French, 2006).

Coastal dunes are rich in various vegetation types and habitats where the nature, distribution and coverage are persistently and continually changing and they are reliant on the balance of environmental and human factors (Arens et al., 2001; DEFRA, 2007). Dunes are a highly valued coastal defense and ecosystem that offer numerous benefits including; ecological diversity and nature conservation, protection of valued residential or industrial developments, high-grade agricultural land and habitats of international conservation; replenishment of depleted beach and near shore during and after storms; and recreation and tourism benefits (Beatley et al., 1994; Carter, 1988; DEFRA, 2007). Compared with other structures of coastal defense, dunes are less visually intrusive, have greater value for wildlife and recreation and are capable of responding more readily to changes in environmental factors (DEFRA, 2007). Dune restoration is thus considered as the adjustment and augmentation of a natural resilience that lowers environmental vulnerability (Shaw et al., 2001)). vander Meulen et al. (2008) argued that effective dune management must be associated with adjacent coast protection, nature conservation, access and recreation, and sustainable commercial activities. The importance of dune protection is not only vital for its values as ecological habitats, but also to prolong the coasts and their various uses (Doody, 1989, cited in vander Meulen et al., 1989).

Development in coastal areas causes the fragmentation of sand dunes into smaller units (Rooney, 2001, cited in Houston et al., 2001) making it more difficult to manage and in some cases causing habitat loss. Urban development on or behind the sand dunes increases the asset value of land but decreases the coastal protection and conservation value of sand dunes which requires maintenance through a high level of defense and dune stabilization both in the position of dunes and sand surface to prevent dangers of blowing out (DEFRA, 2007). Recreational uses such as golfing and horse riding may cause severe damage to dune vegetation, forestry may change the dynamics and ecology of the dune system, and construction activities may even cause permanent destruction of landform features and habitats (DEFRA, 2007). Light recreation pressure can be beneficial in dune areas but in non-regulated coastal environments, they can also cause fragmentation due to prolonged trampling pressure (Varela et al., 2006). Consequently, these environments suffer biodiversity loss and their conservation value declines, calling for expert professional maintenance and management of dunes - a huge challenge in view of their dynamicity and potentially fragile habitats (EUCC, 2000).

The nature in which Hightown dunes are eroding requires the selection of appropriate dune stabilization technique and partnership with local authorities as well as landowners to formulate an integrated approach to manage the coastal dunes (DEFRA, 2007). It is therefore necessary, in order to cope with upcoming challenges of coastal risk and dunes management in light of climate change, to redesign management and maintenance models of biologically important sites (Gaston et al., 2006). By the year 2020, it is projected that over $60 \%$ of the population will reside within $60 \mathrm{~km}$ of the coast (UNCED, 1992). Similarly, Brown and McLachlan (2002) draw 
attention to the increasing trend towards coastal area habitation either to avoid clashes and population stress inland or for leisure. The current trend in Europe, particularly in the UK, is the increasing development around coastal areas and rising number of tourist attractions to these very important and fragile habitats, making management of such areas more crucial and challenging (Jennings, 2004). The Hightown area conforms to this trend of increasing habitation and development.

Coastal communities will be affected by the multifaceted impacts of global climate changes, especially global warming, and many of those communities have already been declared vulnerable to ongoing climatic variability (IPCC, 2001; 2007; Monirul and Mirza, 2003). Among these impacts, sea level rise is considered as one of the prime impacts that may entail tidal inundation, increased flood frequencies, increased coastal erosion, elevated water table and other ecological changes (Nicholls, 2011; IPCC, 2007; Dolan and Walker, 2003). These biophysical changes are associated with some socio-economic impacts including the loss of infrastructures and decline in the economic, ecological, cultural and subsistence values of coastal areas (Klein and Nicholls, 1999). Research shows that global sea level will increase by at least $18 \mathrm{~cm}$ and at most by $59 \mathrm{~cm}$ by the year 2100 (Alley et al., 2007). Sea level rise would bring about the loss of livelihoods and coastal lands, and people will be displaced as a substantial portion of land will go under water (Pender, 2008). Given that half of the world's population live in coastal regions, flooding due to storm surges affect 46 million people per year (La Trobe, 2002). Coastal risks will also make the existing sea defenses unsafe and these unsafe infrastructures will also incur extra cost for maintenance (Pender, 2008). In addition, the extent of dune erosion may increase in the next century as a result of sea level rise and this may cause negative impacts on the dune habitats and the effectiveness of dune system as flood protection will be hampered (DEFRA, 2007).

Planned interventions are needed to tackle dune erosion, particularly where the erosion is continuous in nature (Nordstrom, 2008). In such situations, human efforts to keep hold of shorefront infrastructure in predetermined locations may cause the entire loss of beach, dunes and even the loss of dynamic environments (Nordstrom, 2008). In such cases, there is no alternative but to undertake pragmatic steps both in the form of physical works and management to sustain the beach and dunes (Nordstrom, 2008). To protect vulnerable areas of hinterland from coastal erosion and flooding, a few softer engineering techniques, viable both in economic and environment view points, such as, beach nourishment (on the Lincolnshire Coast), foreshore recharge (on the Orwell Estuary) and managed realignment are been utilized along the UK coasts (Myatt-Bell et al., 2002). Paragraph 9 of the sixth report of the Select Committee on Agriculture of the UK Parliament (SCAS, 1998, cited in French, 2006) states that holding the line of defense is not sustainable for long term management of coastal areas. Therefore, dune management should be targeted to make room for changes for its dynamic conservation.

The Hightown Dune Restoration Project (HDRP) was developed within the framework of accomplishing a balance between future economic affluence and preserving environmental values of the area (Sefton Council, 1997). The principles of sustainable development, biodiversity and the precautionary principle formed the guiding framework of this scheme. Sustainability as a tripartite concept involving social, economic and environmental aspects, requires an awareness of the long term impacts on the environment to enable meeting the needs of the present world at the same time as it creates opportunities to meet the demands of future generations both in terms of quality and quantity of resources, especially where environmental damages appear irreversible (Bell and Morse, 2003; World Commission on Environment and Development, 1987; ENCORA, 2008; Sefton Council, 1997). Sustainable development is aimed at what communities do to and for themselves rather than what is done to them by states, agencies, experts and others (Banerjee, 2003). The principles of sustainability are associated with the precautionary principle which stipulate that coastal resources be managed such that they are not wasted for short-term well-being and that long-term benefits are protected for human and for the natural environments (Taussik, 1996). Therefore, development initiatives require careful planning and implementation for best utilization of resources to conserve or to compensate the natural resource base upon which future development depends (Gilpin, 1996).

\section{Study Area}

The study area - Hightown is located on the bank of the River Alt near the boundary of the Mersey Estuary and the Liverpool Bay, 14Km north of Liverpool City centre, within the jurisdiction of the Sefton Metropolitan Borough Council, Liverpool, North West England (Figure 1). 


\section{ENGLAND}

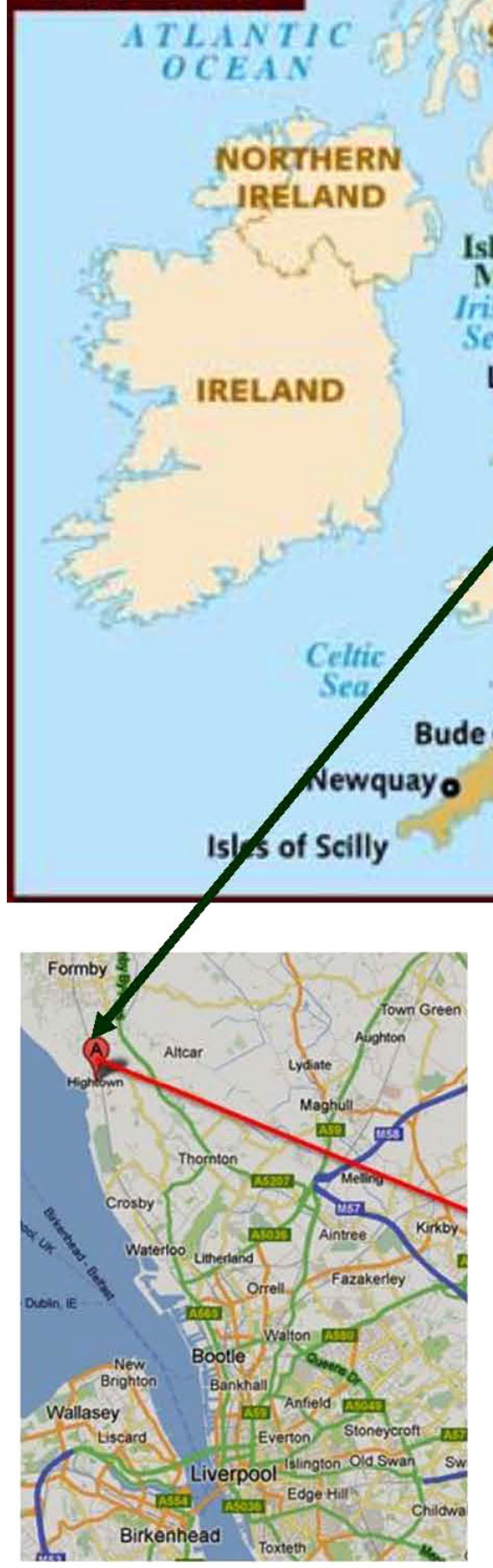

Map of North West England
SCOTLAND

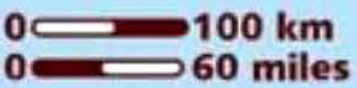

\section{Northumberland}

Carlisle o - Newcastle-upon-tyne Durham

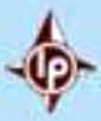

-Lake

Isle of District NP

Man

Irish

Blackpool

$\circ$

Liverpool 0

- Manchester

- York

- Leeds

2. Nottingham

NORTH

$S E A$
- Birmingham Shropshire

\section{WALES The} Bristolo Bath Stonehenge $\bullet$ - Northampton - Oxford olpswich London - Canterbury

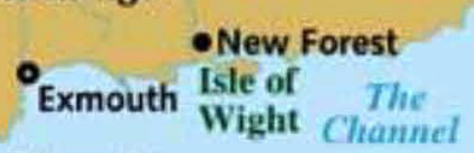

\section{Channel} Islands

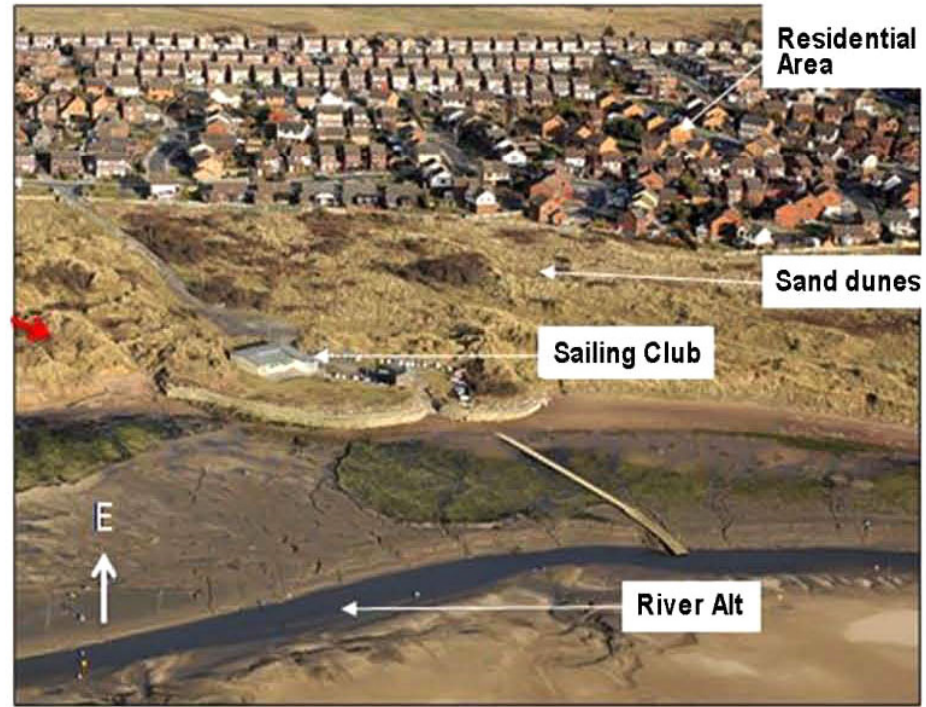

Fig. 1 Hightown Residential area, River Alt and the Blundellsands Sailing Club (Courtesy: North West and North Wales Coastal Group).

Figure 1. Hightown residential area, river alt and the blundellsands sailing club (Courtesy: North west and north wales coastal group)

The River Alt connects the Mersey River at this point and forms an estuary (Hightown Parish Council, 2011). The Merseyrail Northernline divides the Hightown residential area into two: the eastern land zone and the western coastal zone (the study area). The site is a low lying flood prone area with unusual geography and the dunes are 
under constant risks of coastal erosion that might allow the tidal water to enter into the developed residential areas (Adams and Ahmed, 2011). Hightown dunes, famous for its flora, fauna and important habitats for wintering and migrant birds are part of the Sefton Coast Special Site of Scientific Interest (SSSI) (Hightown Parish Council 2011).These dunes extend from Hall Road Coastguard Station in the south to the River Alt in the north (Figure 2).

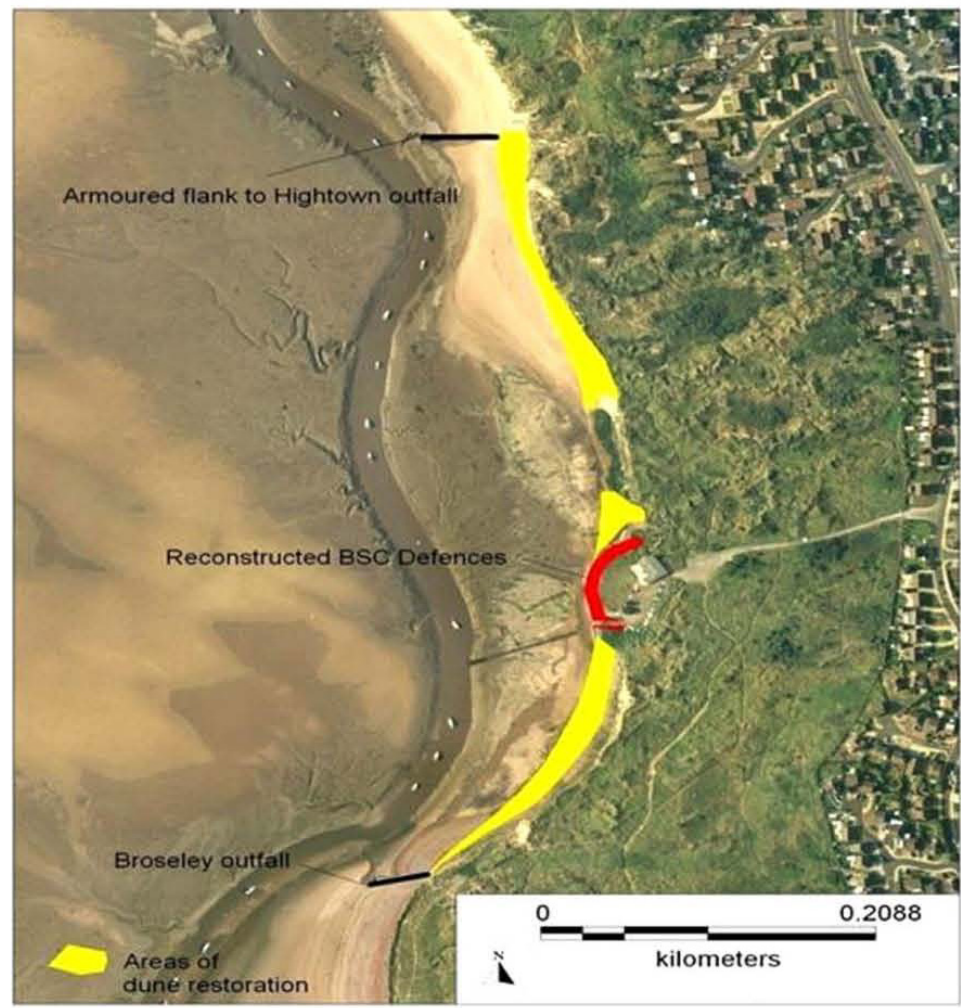

Fig. 2 Coastal Works under Hightown Dune Restoration Project (Courtesy: Sefton Council)

Figure 2. Coastal works under hightown dune restoration project (Courtesy: Sefton council)

Along this dune frontage, which has suffered the impact of an annual erosion rate of 0.5-1 meter per annum over the last 30 years, exists the historic Blundellsands Sailing Club. The continuing dune erosion coupled with low protection of the existing sea defenses and uncertainties in the nature of the Hightown coast due to potential changes in climatic conditions, puts the Sailing Club, the biodiversity and the surrounding residential area at high risk of coastal erosion. Most recent forecasts on the study area indicate sea level rise of around three feet over the next one hundred years and there is potential for increased storminess (Note 1). Against this background the Sefton Council, in a bid to ensure residents' safety and satisfaction and conserve biodiversity, implemented the "Hightown Dunes Restoration Project (HDRP)". The project was made up of three components, namely: (1) creation of a rock groyne adjacent to the outfall of the Sailing Club (2) the reconstruction of the Sailing club defenses and (3) restoration of the sand dunes to the conditions they were in during the late 1970s (Note 2) (Sefton Council 2012; Maritime Journal 2011). It was expected that the rock groyne would enhance the retention of sands on the beach by reducing the wave reflection that had been eroding the dunes, and the restored sand dunes would absorb wave energy to protect the area from coastal erosion. The physical works of the dune restoration project started in September 2011 and were completed in June 2012.

\subsection{Communities around HDRP}

There are 920 households and an approximate population of 2,200 in Hightown (Hightown Parish Council, 2011). To the east of the Merseyrail Northernline there are only 220 households and to the west 700 households. People of varied professions live in this coastal area and have built up a natural relationship with the unique biodiversity, the Blundellsands Sailing Club (BSC) and the coastal issues of the area. Most parts of Hightown were developed as dormitory settlements by a number of developers during the late nineteenth and early twentieth century, while 
the1960's saw the start of housing schemes in Hightown (Adams and Ahmad, 2011; Hightown Parish Council, 2011). At the very beginning of the housing developments in this area in 1960 s, many local people resisted the housing proposals, arguing that the village was not defended against coastal erosion or tidal flooding (Note 3). A public enquiry in 1969 approved the expansion. The area has since and is still experiencing incremental housing pressure although the residents are against further housing expansions.

In this study, the author aims to explore the residents' perceptions toward coastal and dune management in terms of (1) effectiveness of the initiatives of Hightown Dune Restoration Project (HDRP) to protect dunes, the historic Blundellsands Sailing Club, residents' properties and local biodiversity from coastal risks; (2) the extent of community involvement in the project and (3) sustainability and the future challenges of the project. Research questions were focused to extract residents' perceptions in order to achieve the stated goal of the study. Overall conclusions have been drawn from the discussion of the results.

\section{Methods}

\subsection{Data Collection}

The study was based on a qualitative approach that afforded the opportunity to enter into the world of participants to extract their perceptions, experiences, understandings and beliefs on the research theme (Creswell, 2009). Qualitative approach is based on naturalistic, interpretive and participatory perspectives (Merriam, 1998) and enters the research field with no preconceived ideas or guide and it has no strict design, no hypothesis and no limits in its scope or procedure (Sarantakos, 2005). It is particularly essential when the researchers have little knowledge about the area of investigation (Liamputtong and Ezzy, 2005). Semi-structured interviews using open-ended questions were conducted with six Hightown residents and two Sefton Council officials, between June and August 2012. The minimum interview length was 45 minutes and maximum time was 1 hour \& 10 minutes. The interviews were recorded and informed consents were obtained prior to the interviews. The entire conduct of the interviews was guided by institutional ethical guidelines and requirements of anonymity and confidentiality. The interviews were conducted to investigate residents' perceptions of the HDRP initiatives with respect to dunes and coastal risks, safety measures of the Sailing Club and the biological features, community involvement, sustainability and the future challenges of the project. Interview data was transcribed before analysis. Data was categorized and analyzed manually using qualitative content analysis (Mayring, 2000) to generate pertinent themes.

\subsection{Characteristics of the Interviewee}

Participants (6 males and 2 females) were drawn from residents of Hightown who had lived in the area for more than 5 years, were knowledgeable of the project and the features of the area, and were willing to participate in the study and comment on the recent project works. Five respondents were between the ages of 35 and 64 , and two respondents were over the age of 65 . Five of the respondents had a Masters degree.

\section{Results and Discussion}

\subsection{Effectiveness of Dune Stabilization and Restoration Works}

Almost all the respondents opined that the implemented dune restoration measures were not effective and the degraded dunes were not restored properly. They also argued that the sands were blowing out and more efforts were needed to return them to their previous conditions. The respondents stated that the traditional dune management techniques (planting Marram grass and limiting human disturbances) adopted by the project did not yield favorable outcomes. Hightown is very close to the sea, and although current weather conditions are not yet extreme, Nicholls (2011) warns that the impacts of climate change will intensify the storminess of the sea.

'The dunes protect the area from coastal erosion. But the dunes are not settled properly till now. Sands are blowing out but the works have already been stopped. I don't know whether they will start working here soon or not. Actually, I don't know the ways how sands become settled but the present works seem temporary.'

The above comment by a respondent and other warnings may have guided participants' concern that violent winds or storms may cause serious damage to the newly restored but ineffective dunes.

\subsection{Effectiveness of Blundellsands Sailing Club defenses}

With respect to the historic Blundellsands Sailing Club, participants again criticized the effectiveness of the reconstructed defenses to protect the Club from wave reflections and coastal erosion, maintaining that such protection did not reduce the Club's vulnerability to coastal risks. One respondent revealed that the Sefton Council is considering the removal or relocation of the Club. This therefore indicates that even the implementing 
agency appears dissatisfied with the initiatives, and portrays the project as lacking in proper planning.

'The protective works of the Sailing Club looks strong but if the beach erodes, the concrete defence will be risky.'

The above statement by a participant indicates the lack of confidence in the protective measures against future threats and the sustainability of the defense works. In the light of this notion, Nordstrom (2008) warned about constructing hard defences along eroding beach arguing that without planned intervention, human attempts intended to keep hold of shorefront infrastructure in fixed positions might harm the beach and dunes and even the dynamic coastal environment. However, some respondents injected a note of caution, warning that it was too soon to comment on the outcomes of the project.

\subsection{Coastal Risks}

All the respondents expressed concern about the coastal risks of Hightown. The responses ranged from mild concern to outright dissatisfaction. They mentioned coastal erosion, flooding, breaching of sea defense, extraordinary high tide combined with extreme wind speeds and sea level rise as the probable coastal risks. They expressed their views on how coastal risks could affect their properties, flora, fauna and the habitats of the biologically important area. Most of the respondents felt that their properties were safe for the time being but expressed doubts about the safety of their properties in the long term.

As many of the respondents had witnessed changes in the River Alt's course, they felt they were knowledgeable about the impacts of sea level rise and predicted severe floods and tidal surges. They further expressed concern that even the community might be relocated due to the impacts of sea level rise if pragmatic steps both in policy and management couldn't be taken in appropriate time. One respondent argued that not just Hightown but the whole Sefton Coast is vulnerable to the impacts of sea level rise.

'I feel safe now but I don't know what will happen in the coming days. I can't guarantee fearless future for my generation...Tides come twice a day now. As I said there are chances of floods or Tsunami. Are we prepared enough to face those consequences? Might be, it will not affect me in my lifetime, but, I can't say that it wouldn't affect my generation. And, I don't know how severe it could be. I think, this area is not safe from coastal risks in the coming years.'

Accepting that risks are a means of stating uncertainty and a set of perceptions (Raaijmakers et al. 2008) implies that risks should be considered as a sum total of findings rather than a truth (Aven and Kristensen 2005). Thus, the residents' perceptions and uncertainties portray aspects of the coastal risks and vulnerability of the study area.

\subsection{Biodiversity Protection}

With regards to the coastal ecology, many of the respondents displayed high awareness about the biological features of the area, probably because, as one respondent put it, they walk along the coasts and have built up a natural relationship with the area. They are also familiar with the plant species, birds and habitats. They expressed the view that the ineffectiveness of the project initiatives against coastal risks may in turn result in harm to the highly valued flora and fauna.

'....many rare plants like Vipers Bugloss, Bee Orchids and Pyramidal Orchids grow along here. This area is also a good habitat of some rare reptiles like Sand Lizard and Red Squirrel. Sand Lizards have greatly declined. Their habitat has already been lost due to couple of developmental interventions.

Butterflies, the Little Blue and the Emperor Moth, reside in this area and are already under threat.'

Furthermore, their concerns about the biodiversity of the area appear also to be linked to the indirect effects of climate change on the ecological features of the area. Their concerns are well founded considering that while most of the UK's protected areas and SSSIs have been designated assuming steady environmental conditions (Graves and Reavey, 1996), the environment is in constant flux and this has a substantial impact on the flora and fauna. Dockerty et al. (2003) and Klein and Nicholls (1999) show that the declining probability of ecological species in the coastal areas is most likely due to biophysical changes caused by climate change. Therefore, the management patterns of biologically important sites should be redesigned considering the impacts of climate change (Gaston et al., 2006), else many protected areas may lose their current conservation values.

\subsection{Community Involvement}

One respondent pointed out that the residents are the direct beneficiaries of the coast and therefore they should be involved in activities within their area. Although most respondents laid emphasis on the necessity of community participation in the project, especially during the planning and formulation stages, the current state of community involvement was minimal. Some respondents hinted that the residents sometimes did not honor the 
invitations of the Sefton Council concerning the project. Other respondents suggested that the best way the community could be kept up to date on the project was for residents to get involved in the project, as their ideas and comments could help the management to formulate a better and comprehensive plan for this area. They also suggested the community could render voluntary services to assist the Council in controlling illegal fly-tipping, motor cycling and other disrupting human activities. These suggestions echo Ernoul's (2010) findings that public participation in development projects or activities ultimately helps to formulate good policy, enhances accountability, lessens community anxieties and increases the probability of achieving the sustainability of the projects. However, Stojanovic and Ballinger (2009) warn that community participation may generate management misinformation if not properly managed and if the community residents lack adequate knowledge base to contribute to coastal management issues. This gap in the residents' knowledge base may be filled by what almost all the respondents referred to as a coastal risk awareness program. As most respondents agreed that the level of community involvement was low, they believed that an awareness program organized by the Sefton Council could increase the residents' contribution to the project. It is also possible that such an awareness program could increase the residents' capacity to adapt to new climatic conditions, thereby decreasing their sense of vulnerability to coastal risks (IPCC, 1995).

'Peoples are not that much educated and intelligent on environmental issues/risks. They should be aware of these risks. Once they know about the severity of coastal risks, they will feel the necessity to face those risks. Educating residents on costal risk issues is essential.'

One respondent indicated that there were plans in place by the Sefton Council to introduce coastal risks awareness program among the children, as building such awareness now would increase their capacity to adapt to coastal issues as adults. Such a plan considers societal needs and may also contribute to lessening the sense of vulnerability, as Adger (1999) is of the opinion that institutional indifference may hinder societal harmony and increase vulnerability.

\subsection{Sustainability of the Project}

Residents were also interviewed to determine their perceptions about the sustainability of the project. Most of the respondents felt that the sand dunes protection efforts were not sustainable. One respondent questioned the sustainability of the project, maintaining that any coast protection intervention was meant to buy time, and this project was no exception as it was also designed to buy time. Some respondents opined that the project could be sustainable by constantly monitoring, surveying and carrying out necessary maintenance works, and giving priority to issues of safety, biodiversity and sea level rise.

The sustainability of the Sailing Club's defense works was also in doubt. One respondent raised a pertinent question concerning the readiness of the residents to be sustainable. This respondent characterized the defense works as a compromise between the residents' and Sailing Club members' desire for immediate measures on one hand, and the management's consideration of long term measures on the other hand. In this regard therefore, he considered the defense works unsustainable. One respondent called for a less critical stance towards the project, arguing that having to negotiate and accommodate conflicting groups while also attempting to preserve coastal biodiversity, was probably a big obstacle for the Council in achieving high levels of cross-sectoral co-operation.

The WCED (1987), Gilpin (1996) and Taussik (1996) proposed that the essence of sustainable coastal management and development is achieved through careful planning that utilizes resources to meet present needs without compromising the resource base for the needs of future generations. Such a balance was not being achieved in the HDRP, leading to the residents' perceptions that the sustainability of the project was low.

\subsection{Future Challenges for Sefton Council}

The respondents pointed out a number of issues as future challenges for Sefton Council for the betterment of the area. They pointed out that the council needed to develop a comprehensive coastal management plan to incorporate control of coastal erosion and flooding, conservation of dune ecology and biological diversity, and mitigation of the effects of human activities. Belfiore (2003) underscored this requirement for a comprehensive plan in order to avoid inappropriate coastal development and indiscriminate coastal degradation. A comprehensive plan would also allow the Sefton Council to accommodate the views of all stakeholders without compromising the requirements of the UK 1949 Coast Protection Act and other environmental agencies. Some respondents also suggested that the project's management might consider the possible relocation of the Blundellsands Sailing Club and restriction of further housing developments as they feel the area is already overstretched. However, considering the fact that the Blundellsands Sailing Club is a historical landmark of Hightown, relocating the club may not be a feasible option as this may meet with stiff resistance from the residents. 


\section{Conclusions}

The findings of the study suggest that the implemented measures are regarded as temporarily effective, but inadequate to achieve the stated aims of the projects on a permanent basis, especially when the threats of climate change and the attendant sea level rise is considered. Respondents also were of the opinion that their vulnerability to coastal risks had not been addressed; the safety of their properties and preservation of the diverse ecological features of the area had not been adequately achieved. Community involvement in the project was minimal and the sustainability of the project was questioned. Respondents proposed that with community participation, the sustainability of the project could be increased. They believed community involvement could be encouraged by creating an awareness of coastal risks and dune management systems. They also felt that the Sefton Council, in addition to developing a comprehensive coastal management plan to accommodate the views of all stakeholders, should control further housing developments. On the basis therefore of the findings, I recommend that a comprehensive long-term coast and dune management plan is required to conserve and protect the coast, dunes, Sailing Club and the biological features of Hightown. Sustainability should be the guiding principle of the Sefton Council in formulating new development schemes considering economic advantages, environmental impacts and the needs and concerns of residents. I also propose to ensure community involvement in the formulation stage of coastal defense plan and to intensify efforts to realize the coastal risks to ensure the sustainability of any coastal defense initiatives. The Sefton Council might consider the use of directives and regulations to restrict further housing development by developers and control damaging activities such as illegal fly-tipping and motorcycling. The author also feel that a detailed study is needed on the impacts of constructing the rock groynes to the outfall of the Sailing Club. Such a study should also focus on identifying suitable coast protection options considering the geographical characteristics of the area and the changing nature of the River Alt.

The present study provides Sefton Council management with an understanding of residents' perception toward coastal and dune management, particularly the effectiveness of HDRP initiatives. The findings may enable them to accommodate residents' concerns in future planning and to gain support for coastal and dune preservation initiatives. Furthermore, the study opens up the prospect of dialogue and collaboration between Sefton Council and Hightown residents. The study has afforded Hightown residents the opportunity to air their opinions about the project. A larger-scale study is needed that includes more Hightown residents to provide more information on how widespread the views are expressed in this study.

\section{Acknowledgements}

Special thanks first of all to the Government of Bangladesh for sanctioning my deputation and granting the scholarship that enabled my successful study and the project work in the UK. My sincere appreciation and gratitude to my research supervisor Mr. Paul Rooney, Senior Lecturer of the Department of Geography and Environmental Science, Liverpool Hope University, the UK, for his guidance and encouragement throughout the research work. I am highly indebted to Mr. Graham Lymbery of Sefton Metropolitan Borough Council, Liverpool, Mr. David Warren, Ex-Chairman of Hightown Parish Council and Mr. Tim Ashbury, Chairman of Hightown Parish Council for their absolute cooperation during the field survey and data collection stages of this research.

\section{References}

Adams, M., \& Ahmad, C. (2011). An Archaeological Assessment of the Hightown Dunes: Dune Restoration Works Proposal. National Museums Liverpool Field Archaeology Unit, Liverpool. Retrieved March 4, 2012, from http://forms.sefton.gov.uk/planning/S_2011_0242_Others_Appendix\%2011\%20\%20Archaeologic al\%20Assessment.pdf

Adger, W. N. (1999). Social vulnerability to climate change and extremes in coastal Vietnam. World Development, 27, 249-269. http://dx.doi.org/10.1016/S0305-750X(98)00136-3

Alkan, H., Korkmaz, M., \& Tolunay, A. (2009). Assessment of primary factors causing positive or negative local perceptions on protected areas. Journal of Environmental Engineering and Landscape Management, 17(1), 20-27. http://dx.doi.org/10.3846/1648-6897.2009.17.20-27

Alley, R. B. et al. (2007). Contribution of Working Group I to the Fourth Assessment Report of the Intergovernmental Panel on Climate Change: Summary for Policymakers. IPCC Secretariat: Geneva, Switzerland.

Arens, S. M., Jungerius, P. D., \& van der Meulen, F. (2001). Coastal Dunes. In A. Warren, \& J. R. French (Eds.), Habitat Conservation: Managing the Physical Environment. Wiley. 
Aven, T., \& Kristensen, V. (2005). Perspectives on risk: review and discussion of the basis for establishing a unified and holistic approach. Reliability Engineering and System Safety, 90(1), 1-14. http://dx.doi.org/10.1016/j.ress.2004.10.008

Banerjee, S. B. (2003). Who Sustains Whose Development? Sustainable Development and Reinvention of Nature. Organization Studies, 24, 143-180. http://dx.doi.org/10.1177/0170840603024001341

Beatley, T., Brower, D., \& Schwab, A. (1994). Introduction to coastal zone management. Washington DC: Island Press.

Belfiore, S. (2003). The growth of integrated coastal management and the role of indicators in integrated coastal management: introduction to the special issue. Ocean and Coastal Management, 46, 225-234. http://dx.doi.org/10.1016/S0964-5691(03)00005-X

Bell, S. (2001). Landscape pattern, perception and visualization in the visual management of forests. Landscape Urban Planning, 54, 201-211. http://dx.doi.org/10.1016/S0169-2046(01)00136-0

Bell, S., \& Morse, S. (2003). Measuring Sustainability: Learning by Doing. Earthscan, London.

Brown, A. C., \& McLachlan, A. (2002). Sandy Shore Ecosystems and the Threats Facing them: Some Predictions for the Year 2025. Environmental Conservation, 29, 62-67. http://dx.doi.org/10.1017/S037689290200005X

Campos, M., Velázquez, A., Verdinelli, G. B., Priego-Santander, A. G., McCall, M. K., \& Boada, M. (2012). Rural people's knowledge and perception of landscape: A case study from the Mexican Pacific Coast. Society \& Natural Resources: An International Journal, 25, 759-774. http://dx.doi.org/10.1080/08941920.2011.606458

Carter, R. W. G. (1988). Coastal Environments: An introduction to the physical, ecological and cultural systems of coastlines. Academic Press.

Creswell, J. W. (2009). Research design: qualitative, quantitative and mixed method approaches (3rd ed). Sage.

Department for Environment, Food and Rural Affairs (DEFRA). (2007). Sand dune processes and management for flood and coastal defense, Part 4: Techniques for sand dune management. Retrieved August 13, 2012, from http://evidence.environmentagency.gov.uk/FCERM/Libraries/FCERM_Project_Documents /FD1302_5398_TRP_pdf.sflb.ashx

Dockerty, T., Lovett, A., \& Watkinson, A. (2003). Climate change and nature reserves: examining the potential impacts, with examples from Great Britain. Global Environmental Change, 13, 125-135. http://dx.doi.org/10.1016/S0959-3780(03)00010-4

Dolan, A. H., \& Walker, I. J. (2003). Understanding Vulnerability of Coastal Communities to Climate Change Related Risks (Proceedings of the 8th International Coastal Symposium). Journal of Coastal Research. Special Issue No. 39. Retrieved August 14, 2012, from http://cip2008.cip-icu.ca/_CMS/Files/dolan.pdf

Doody, J. P. (1989). Conservation and development of the coastal dunes in Great Britain. In F. vander Meulen, P. D. Jungerius, \& J. H. Visser (Eds.), Perspectives in Coastal Dunes Management. SPB Academic Publishing. The Netherlands.

ENCORA. (2008). European action plan for strengthening the knowledge base of sustainable coastal and marine management. Centre for Water Management, Rijkswaterstaat, Ministry of Transport, Public Works and Water Management, The Netherlands ENCORA Coordination Action.

Ernoul, L. (2010). Combining process and output indicators to evaluate participation and sustainability in integrated coastal zone management projects. Ocean \& Coastal Management, 53, 711-716. http://dx.doi.org/10.1016/j.ocecoaman.2010.10.001

European Commission. (2010). Science for Environmental Policy. DG Environment News Alert Service: Coastal Management.

European Parliament and Council. (2002). Recommendation of the European Parliament and of the Council of 30 May 2002 concerning the implementation of the integrated coastal zone management in Europe (2002/413/EC).

European Union for Coastal Conservation (EUCC). (2000). Coastal guide on dune. Retrieved August 16, 2012, from http://www.coastalguide.org/dune/

French, P. W. (2004). The changing nature of, and approaches to, the UK coastal management at the start of the twenty-first century. The Geographical Journal, 170(2), 116-125. http://dx.doi.org/10.1111/j.0016-7398.2004.00113.x

French, P. W. (2006). Managed realignment- The developing story of a comparatively new approach to soft 
engineering. Estuarine Coastal and Shelf Science, 67, 409-423. http://dx.doi.org/10.1016/j.ecss.2005.11.035

Gaston, K. J. et al. (2006). The Ecological Effectiveness of Protected Areas: The United Kingdom. Biological Conservation, 132, 76-87. http://dx.doi.org/10.1016/j.biocon.2006.03.013

Gilpin, A. (1996). Environmental Impact Assessment. Cutting Edge for the Twenty First Century. Cambridge University Press.

Graves, J., \& Reavey, D. (1996). Global Environmental Change. Plants, Animals, and Communities. Longman, Essex.

Hightown Parish Council. (2011). Parish Plan, Final Approved Version, 16th May 2011. Retrieved August 7, 2012, from http://www.hightownvillage.org/page45.php

Htun, N. Z., Mizoue, N., \& Yoshida, S. (2012). Determinants of local people's perceptions and attitudes toward a protected area and its management: A case study from Popa Mountain Park, Central Myanmar. Society and Natural Resources: An International Journal, 25(8), 743-758. http://dx.doi.org/10.1080/08941920.2011.620597

IPCC. (1995). Second Assessment Report: Economic and Social Dimension of Climate Change. Intergovernmental Panel on Climate Change (IPCC). Cambridge University Press, UK.

IPCC. (2001). Climate Change: Impacts, Adaptation, and Vulnerability. Contribution of Working Group II to the third assessment report of the Intergovernmental Panel on Climate Change (IPCC). Cambridge University Press, New York.

IPCC. (2007). Climate Change-Impacts, Adaptation and Vulnerability. Contribution of Working Group II to the Fourth Assessment Report of the Intergovernmental University Press, UK.

Jennings, S. (2004). Coastal Tourism and Shoreline Management. Journal of Tourism Research, 31(4), 899-922. http://dx.doi.org/10.1016/j.annals.2004.02.005

Jim, C. Y., \& Xu, S. S. W. (2002). Stifled Stakeholders and subdued participation: Interpreting local responses toward Shimentai Nature Reserve in South China. Environmental Management, 30(3), 327-341. http://dx.doi.org/10.1007/s00267-002-2623-9

King, G. (2003). The role of participation in the European Demonstration Projects in ICZM. Coastal Management, 31, 137-143. http://dx.doi.org/10.1080/08920750390168354

Klein, R. J. T., \& Nicholls, R. J. (1999). Assessment of coastal vulnerability to climate change. Ambio, 28(2), 182-187.

La Trobe, S. (2002). Climate and Poverty-A Discussion Paper. Teddington, Middlesex, UK: Tearfund.

Liamputtong, P., \& Ezzy, D. (2005). Qualitative research methods (2nd ed.). Oxford University Press, London.

Maritime Journal. (2011). Work Commences on Hightown Coastal Defences. Retrieved August 8, 2012, from http://www.maritimejournal.com/features101/marine-civils/port,-harbour-and-marineconstruction/workcom mences-on-hightown-coastal-defences

Mayring, P. (2000). Qualitative Content Analysis [28 Paragraphs]. Forum: Qualitative Social Research, 1(2).

McKenna, J., \& Cooper, A. (2006). Sacred cows in coastal management: the need for a 'cheap and transitory' model. Area, 38(4), 421-431. http://dx.doi.org/10.1111/j.1475-4762.2006.00708.x

Merriam, S. (1998). Qualitative research and case study applications in education. Jossy Bass, San Francisco.

Monirul, M., \& Mirza, Q. (2003). Climate change and extreme weather events: Can developing countries adapt? Climate Policy, 3, 233-248. http://dx.doi.org/10.3763/cpol.2003.0330

Myatt-Bell, L. B., Scrimshaw, M. D., \& Lester, J. N. (2002). Public perceptions of managed realignment: Brancaster West Marsh, North Norfolk, UK. Marine Policy, 26, 45-57. http://dx.doi.org/10.1016/S0308-597X(01)00033-1

Nicholls, R. J. (2011). Planning for the impacts of sea level rise. Oceanography, 24, 144-157. http://dx.doi.org/10.5670/oceanog.2011.34

Nordstrom, K. F. (2008). Beach and Dune Restoration. Cambridge University Press. http://dx.doi.org/10.1017/cbo9780511535925

Pender, J. S. (2008). What Is Climate Change? And How It will Effect Bangladesh? Briefing Paper (Final Draft). Dhaka, Bangladesh: Church of Bangladesh Social Development Program.

Raaijmakers, R., Krywkow, J., \& vanderVeen, A. (2008). Flood risk perceptions and spatial multi criteria analysis: an exploratory research for hazard mitigation. Department of water engineering and management, 
University of Twente, The Netherlands. http://dx.doi.org/10.1007/s11069-007-9189-z

Rooney, P. J. (2001). The Sefton Coast Life Project: a conservation strategy for the sand dunes of the Sefton Coast, northwest England. In J. A. Houston, S. Edmondson, \& P. J. Rooney (Eds.), Coastal Dune Management-Shared Experience of European Conservation Practice. Liverpool University Press.

Roth, R. (2004). Spatial organization of environmental knowledge: Conservation conflicts in the inhabited forest of northern Thailand. Ecology and Society, 9(3), 5.

Sarantakos, S. (2005). Social research (3rd ed.). Palgrave Macmillan, New York.

Sefton Council. (1997). The Sefton Coast Management Plan: 1997-2006, 2nd Review, Sefton Council, Formby, England.

Sefton Council. (2012). Hightown Dune Restoration Project. Retrieved August 15, 2012, from http://www.sefton.gov.uk/default.aspx?page=10964

Select Committee on Agriculture Sixth Report (SCAS). (1998). Flood and Coastal Defense. The United Kingdom Parliament. In : French, P. W. 2006. Managed realignment- The developing story of a comparatively new approach to soft engineering. Estuarine Coastal and Shelf Science, 67, 409-423. http://dx.doi.org/10.1016/j.ecss.2005.11.035

Shaw, R. W., \& Climate Change Action Fund (CCAF) Project Team. (2001). Coastal Impacts of Climate Change and Sea-Level Rise on Prince Edward Island: Synthesis Report. Environment Canada, Natural Resources Canada, Fisheries \& Oceans Canada, Dartmouth, Canada. Retrieved February 28, 2013, from http://www.coastalchange.ca/download_files/external_reports/Shaw_\%282001\%29_CoastalImpactsofClima teChangeandSLRonPEI.pdf

Stojanovic, T., \& Ballinger, R. C. (2009). Integrated Coastal Management: A comparative analysis of four UK initiatives. Applied Geography, 29, 49-62. http://dx.doi.org/10.1016/j.apgeog.2008.07.005

Taussik, J. (1996). Development Plans and the coastal zones. Town Planning Review, 67(4), 397-416. http://dx.doi.org/10.3828/tpr.67.4.w18121171r466u67

United Nations Conference on Environment and Development. (1992). Agenda 21: Chapter:17. UNCED.

van der Meulen, F., Bakker, T. W. M., \& Houston, J. A.. (2008). The Costs of our Coasts: Examples of dynamic dune management from Western Europe. Ecological Studies, 171, 259-277. http://dx.doi.org/10.1007/978-3-540-74002-5_16

Varela, D. R. A., Rego, R. P., \& Iglesias, C. M. S. (2006). Tracking environmental impacts and habitat fragmentation on coastal protected areas through object oriented Analysis-Identification and Categorization of Linear Disturbances in Corrubedo Natural Park (NW Iberian Peninsula). Bridging Remote Sensing and GIS, 36-4/C42.

Warren, M. D., Slikkerveer, J., \& Brokensha, D. (1995). The cultural dimension of development: Indigenous knowledge systems. London: Intermediate Technology Publications. http://dx.doi.org/10.3362/9781780444734

World Commission on Environment and Development (WCED). (1987). Our common future. Oxford University Press, Oxford.

Xu, J., Chen, L., Lu, Y., \& Fu, B. (2006). Local people's perceptions as decision support for protected area management in Wolong Biosphere Reserve, China. Journal of Environmental Management, 78, 362-372. http://dx.doi.org/10.1016/j.jenvman.2005.05.003

\section{Notes}

Note 1. This information was conveyed through personal communication with a project staff of Sefton Council.

Note 2. It is believed that in the late 1970s the dunes were stable in nature and erosion was not prevalent at that time.

Note 3. This information was conveyed through personal communication with a resident of Hightown.

\section{Copyrights}

Copyright for this article is retained by the author(s), with first publication rights granted to the journal.

This is an open-access article distributed under the terms and conditions of the Creative Commons Attribution license (http://creativecommons.org/licenses/by/3.0/). 